\title{
July 2013 Critical Care Journal Club
}

This month we focused on prone ventilation in our journal club. Fellows Josh Jewell, Elijah Poulos, Heemesh Seth, Suresh Uppalapu, Nithya Menon, Sandra Till and Nick Sparacino presented articles. Faculty including Rick Robbins, Al Thomas, Jay Blum, Huw Owen Reece, Roxanne Garcia Orr, Dick Gerkin and Bob Raschke were present, and Dr. Shiva Birdi attended and assisted our discussion (thanks).

This Journal Club was prompted by a randomized controlled trial published recently in the NEJM that showed that mortality of severe ARDS could be dramatically reduced by prone ventilation. Our current practice has been based on previous findings that proning could improve oxygenation, but not mortality. Proning is currently considered a rescue therapy by most clinicians, to be used when ARDSnet ventilator settings fail to provide adequate oxygenation. Therefore, this study had the potential to significantly change practice.

Prone positioning during mechanical ventilation is thought to improve oxygenation by several gravitational mechanisms. In the supine position, dorsal transpulmonary pressure is less than ventral transpulmonary pressure. Transpulmonary pressure is related to alveolar filling. Proning reduces the difference between dorsal and ventral transpulmonary pressures, ameliorating both dorsal atelectasis and ventral alveolar over-distention that occur in the supine position. The second of these effects might theoretically reduce the incidence of ventilator-associated lung injury. Additionally, proning relieves compression of dorsal lung by the weight of the heart, lungs, and abdomen. The dorsal lung continues to receive the majority of pulmonary blood flow in the prone position; therefore, as dorsal atelectasis is reduced, V/Q matching improves.

The focus of our discussion - Guerin's randomized controlled trial (RCT) - should be considered in the context of previous RCTs. Table 1 presents an overview of this context. Note that the earlier studies lacked detail in their methods sections, and some reported significant cross-over between treatment and control groups, reducing their methodological quality. Over the course of the last 12 years, researchers have increasingly focused their attention on more severe forms of ARDS, as can be seen by the falling $\mathrm{p}_{\mathrm{a}} \mathrm{O}_{2} / \mathrm{FiO}_{2}$ of eligible patients over time. Earlier studies did not employ ARDSnet ventilator settings, and may no longer be as clinically applicable.

Researchers have increasingly sought to start proning earlier, and maintain it for longer periods throughout each day of mechanical ventilation. In Guerin's study, patients spent $73 \%$ of their ventilator time proned. Mortality outcomes are difficult to compare, because studies varied in reporting ICU-mortality, 10-day mortality, 28-day mortality and 60-day mortality - with a general trend towards longer-term follow-up in more recent

studies. Overall, the results of Guerin's study stand out in this comparison. The dramatic reduction in mortality by over half is unheralded by the earlier studies. The pvalue of 0.001 shows that the results even surprised the statisticians who calculated the sample size of the study. Only Taccone's study reported significant incidence of what seem to us to be relatively common complications of prone ventilation. Many of the clinicians present at our journal club have personally witnessed cardiopulmonary instability, and the inadvertent discontinuation of IV catheters or the endotracheal tube (ETT) during the proning maneuver. 
Table 1: Randomized controlled trials of prone ventilation that reported mortality outcomes.

\begin{tabular}{|c|c|c|c|c|c|c|c|}
\hline & $\begin{array}{l}\text { Quali } \\
\text { ty }\end{array}$ & $\mathrm{N}$ & $\begin{array}{l}\mathrm{p}_{\mathrm{a}} \mathrm{O}_{2} / \mathrm{Fi} \\
\mathrm{O}_{2}\end{array}$ & $\begin{array}{l}\text { ARDS } \\
- \\
\text { net } \\
\text { TV }\end{array}$ & $\begin{array}{l}\text { Start of } \\
\text { pronin } \\
\text { g } \\
\text { (hrs) }\end{array}$ & $\begin{array}{l}\text { Dose of } \\
\text { proning } \\
\text { (hrs/da } \\
\text { y) }\end{array}$ & $\begin{array}{l}\text { Outcomes: } \\
\text { Mortality (Prone vs. } \\
\text { control) } \\
\text { [complications] }\end{array}$ \\
\hline $\begin{array}{l}\text { Gattinoni } \\
2001 \\
(1)\end{array}$ & + & 304 & $<300$ & - & $?$ & 7 & $\begin{array}{l}51 \text { vs } 48 \% \text { p=ns } \\
\text { (ICU mortality) } \\
\text { [more pressure sores } \\
\text { with proning] }\end{array}$ \\
\hline $\begin{array}{l}\text { Manceb } \\
0 \\
2006 \\
(2)\end{array}$ & + & 136 & $<200$ & - & $\leq 72$ & 17 & $\begin{array}{l}43 \text { vs } 58 \% p=0.12 \\
\text { (ICU mortality) }\end{array}$ \\
\hline $\begin{array}{l}\text { Fernand } \\
\text { ez } \\
2008 \\
(3)\end{array}$ & + & 40 & $<200$ & + & $\leq 48$ & 20 & $\begin{array}{l}38 \text { vs } 53 \% p=0.3 \\
\text { ( } 60 \text { day mortality) }\end{array}$ \\
\hline $\begin{array}{l}\text { Taccone } \\
2009 \\
(4)\end{array}$ & ++ & 342 & $<200$ & + & $\leq 72$ & 18 & $\begin{array}{l}31 \text { vs } 33 \% \mathrm{p}=0.72 \\
\text { (28 day mortality) } \\
\text { [increased sedation } \\
\text { requirement, airway } \\
\text { obstruction, } \\
\text { desaturation, } \\
\text { hemodynamic } \\
\text { instability, and } \\
\text { accidental venous } \\
\text { access loss with } \\
\text { proning] }\end{array}$ \\
\hline $\begin{array}{l}\text { Guerin } \\
2013 \\
\text { (5) }\end{array}$ & ++ & 466 & $<150$ & + & $\leq 25$ & $\geq 16$ & $\begin{array}{l}16 \text { vs } 33 \% \mathrm{p}=0.001 \\
\text { ( } 28 \text { day mortality) } \\
\text { [Cardiac arrest higher } \\
\text { in control group] }\end{array}$ \\
\hline
\end{tabular}

Guerin's study appears to meet many criteria for a well-conducted RCT (6) specifically, their follow-up was adequate, the groups were treated equally except for the intervention, intention-to-treat analysis was employed, and clinically-significant and statistically-precise effect size was demonstrated. The patients in the study seemed similar to ones that we typically care for (i.e., the results seem generalizable). A few potential problems with internal validity were noted. The randomization did not appear to have been concealed, and control group had statistically worse SOFA scores and higher vasopressor requirements, indicating that they were sicker at baseline. 
Their results indicate a "number-needed-to-treat" of six - that is, a life was saved for every six patients who underwent prone ventilation. The magnitude of this effect size is greater than for any other well-studied intervention in critical care. It is our consensus that this result is too good to be true, and will require confirmation by further studies before proning ought to be routinely recommended for patients with severe ARDS $\left(\mathrm{p}_{\mathrm{a}} \mathrm{O}_{2} / \mathrm{FiO}_{2} \leq 150\right)$. Our opinion is consistent with the larger context of randomized controlled trials in the field of critical care - we are often ultimately disappointed by treatments that appear to have significant mortality benefit in a single randomized controlled trial (e.g. use of Swan-Ganz catheters to guide goal-directed resuscitation, corticosteroids for ARDS, Ha-1a for septic shock, corticosteroids for septic shock, drotrecogin-alfa for septic shock, tight glucose control in critical illness, etc.). Finally, we noted that the low complication rate in Guerin's study likely understates the potential difficulties of proning in most institutions.

The point is well-taken that our current compliance with ARDSnet low tidal volume mechanical ventilation is suboptimal. We can likely best benefit our patients at the current time by focusing system-level quality improvement efforts on this foundational aspect of ventilator care, until more is known about the potential benefits of proning. In the meantime, we retain prone ventilation as a rescue therapy, but will be more likely to consider it favorably in comparison to other rescue therapies such as inhaled nitric oxide, which have less evidence to suggest clinical benefit.

Robert A. Raschke, MD, MS

Associate Editor

\section{References}

1. Gattinoni L, Tognoni G, Pesenti A, Taccone P, Mascheroni D, Labarta V, Malacrida R, Di Giulio P, Fumagalli R, Pelosi P, Brazzi L, Latini R; Prone-Supine Study Group. Effect of prone positioning on the survival of patients with acute respiratory failure. $\mathrm{N}$ Engl J Med. 2001;345(8):568-73. [CrossRef] [PubMed]

2. Mancebo J, Fernández R, Blanch L, Rialp G, Gordo F, Ferrer M, Rodríguez F, Garro P, Ricart P, Vallverdú I, Gich I, Casta-o J, Saura P, Domínguez G, Bonet A, Albert RK. A multicenter trial of prolonged prone ventilation in severe acute respiratory distress syndrome. Am J Respir Crit Care Med. 2006;173(11):1233-9. [CrossRef] [PubMed]

3. Fernandez R, Trenchs X, Klamburg J, Castedo J, Serrano JM, Besso G, Tirapu JP, Santos A, Mas A, Parraga M, Jubert P, Frutos F, A-on JM, Garcia M, Rodriguez F, Yebenes JC, Lopez MJ. Prone positioning in acute respiratory distress syndrome: A multicenter randomized clinical trial. Intensive Care Med. 2008;34(8):1487-91. [CrossRef] [PubMed]

4. Taccone $P$, Pesenti A, Latini R, Polli F, Vagginelli F, Mietto C, Caspani L, Raimondi F, Bordone G, lapichino G, Mancebo J, Guérin C, Ayzac L, Blanch L, Fumagalli R, Tognoni G, Gattinoni L; Prone-Supine II Study Group. Prone positioning in patients with moderate and severe acute respiratory distress syndrome. JAMA. 2009;302(18):1977-84. [CrossRef] [PubMed] 
5. Guérin C, Reignier J, Richard JC, Beuret P, Gacouin A, Boulain T, Mercier E, Badet M, Mercat A, Baudin O, Clavel M, Chatellier D, Jaber S, Rosselli S, Mancebo J, Sirodot M, Hilbert G, Bengler C, Richecoeur J, Gainnier M, Bayle F, Bourdin G, Leray V, Girard R, Baboi L, Ayzac L; PROSEVA Study Group. Prone positioning in severe acute respiratory distress syndrome. N Engl J Med. 2013;368(23):2159-68. [CrossRef] [PubMed]

6. Guyatt GH, Sackett DL, Cook DJ. User's Guides to the medical literature: How to use an article about therapy or prevention. Are the results of the study valid? JAMA. 1993;270(21):2598-2601. [CrossRef] [PubMed] 